
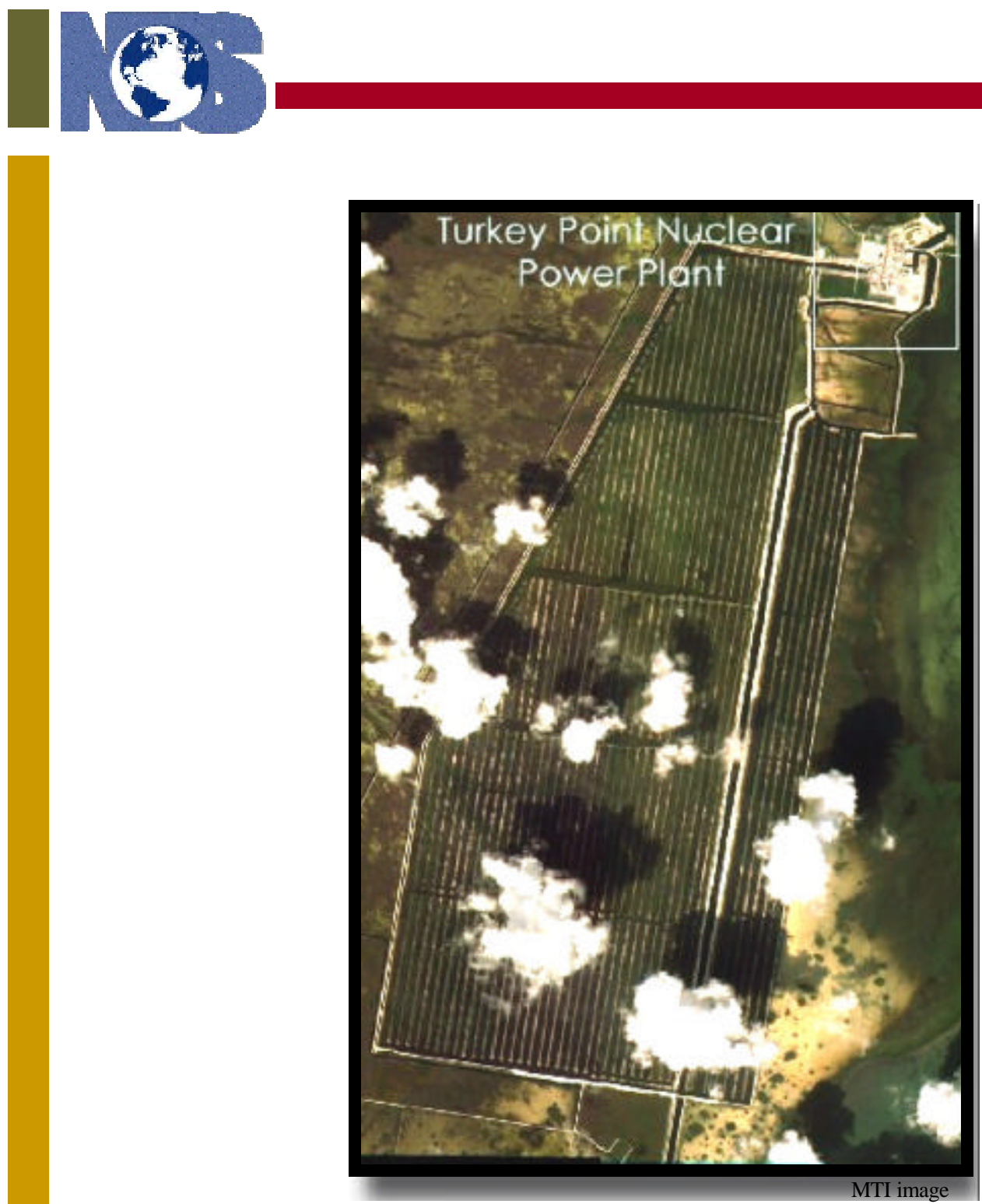

\title{
Final MTI Data Report: Turkey Point Nuclear Power Plant (U)
}

Westinghouse Savannah River Company October 2002 Savannah River Site Aiken, SC 29808 
This document was prepared in conjunction with work accomplished under Contract No. DE-AC09-96SR18500 with the U. S. Department of Energy.

\section{DISCLAIMER}

This report was prepared as an account of work sponsored by an agency of the United States Government. Neither the United States Government nor any agency thereof, nor any of their employees, makes any warranty, express or implied, or assumes any legal liability or responsibility for the accuracy, completeness, or usefulness of any information, apparatus, product or process disclosed, or represents that its use would not infringe privately owned rights. Reference herein to any specific commercial product, process or service by trade name, trademark, manufacturer, or otherwise does not necessarily constitute or imply its endorsement, recommendation, or favoring by the United States Government or any agency thereof. The views and opinions of authors expressed herein do not necessarily state or reflect those of the United States Government or any agency thereof.

This report has been reproduced directly from the best available copy.

Available for sale to the public, in paper, from: U.S. Department of Commerce, National Technical Information Service, 5285 Port Royal Road, Springfield, VA 22161, phone: (800) 553-6847, fax: (703) 605-6900

email: orders@ntis.fedworld.gov

online ordering: http://www.ntis.gov/help/index.asp

Available electronically at http://www.osti.gov/bridge

Available for a processing fee to U.S. Department of Energy and its contractors, in paper, from: U.S. Department of Energy, Office of Scientific and Technical Information, P.O. Box 62, Oak Ridge, TN 37831-0062,

phone: (865)576-8401,

fax: (865)576-5728

email: $\underline{\text { reports@ adonis.osti.gov }}$ 


\title{
Final MTI Data Report: Turkey Point Nuclear Power Plant (U)
}

\author{
Prepared by \\ M. J. Parker and A. J. Garrett \\ Westinghouse Savannah River Company \\ Aiken, South Carolina, 29808
}

October 2002 
WSRC-TR-2002-00489

Final MTI Data Report: Turkey Point Nuclear Power Plant (U)

Savannah River Technology Center

This page intentionally left blank. 


\section{TABLE OF CONTENTS}

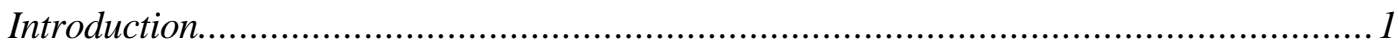

Surface Water Temperature Measurements ………………................................. 1

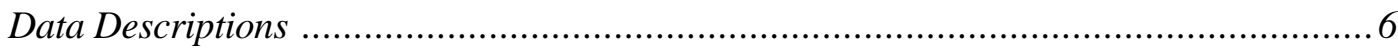

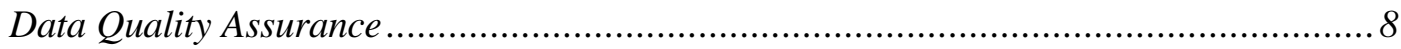

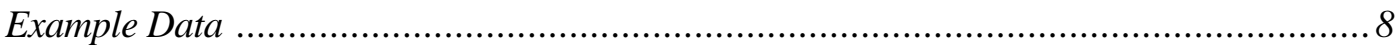

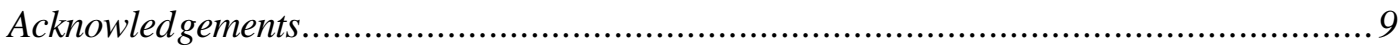

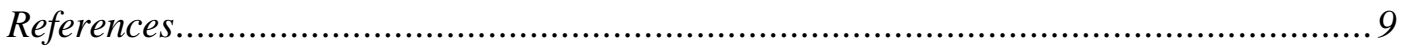

\section{LIST OF FIGURES}

Figure 1. The Location of the Turkey Point Nuclear Power Plant .............................. 1

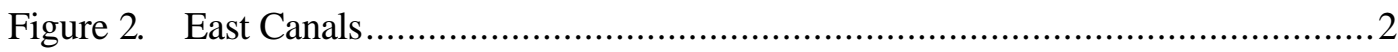

Figure 3. Network of Cooling Canals............................................................. 2

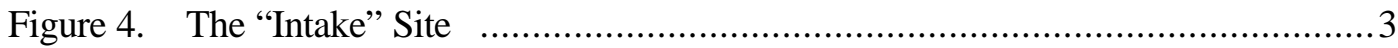

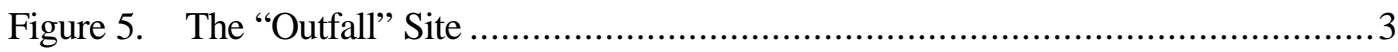

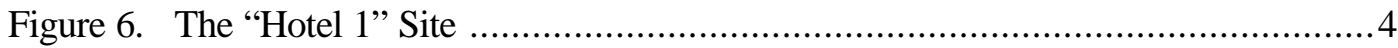

Figure 7 Location of Water Temperature Monitoring Sites................................... 4

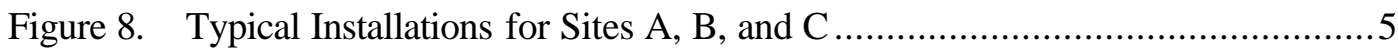

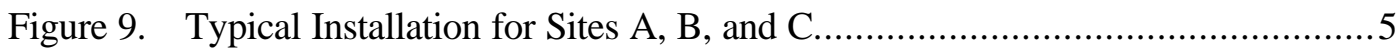

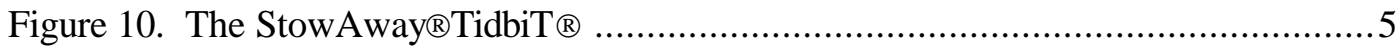

Figure 11. Photograph of an American Crocodile in a Cooling Canal ............................5

Figure 12. Time Series Plot of Water Temperature Data Collected at Sites A, B, and C ...8

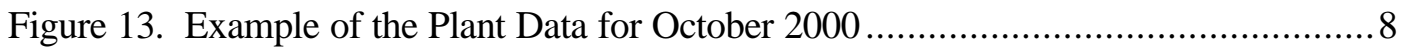


WSRC-TR-2002-00489

Final MTI Data Report: Turkey Point Nuclear Power Plant (U)

Savannah River Technology Center

\section{LIST OF TABLES}

Table I. Description of Data Nomenclature ........................................................... 6 


\section{INTRODUCTION}

During the period from September 2000 to April 2002, surface water temperature data was collected at the Turkey Point Nuclear Power Plant near Homestead, FL (Figure 1). This effort was led by the Savannah River Technology Center (SRTC) with the assistance of local plant personnel. Permission for setting up the monitoring sites was granted by Florida Power \& Light, which owns the plant site. This work was done in support SRTC's ground truth mission for the US Department of Energy's Multispectral Thermal Imager (MTI) satellite (Garrett, et al, 1999). Data described in this report are available from the authors (contact information provided at the end of report).

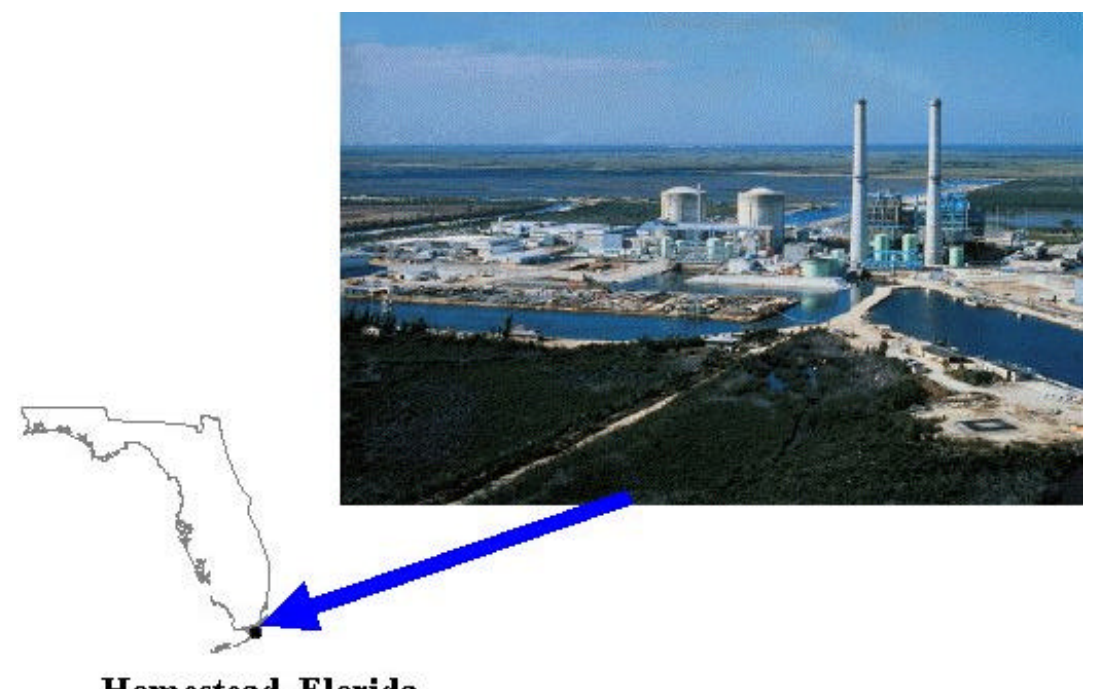

Homestead, Florida

Figure 1. The location of the Turkey Point Nuclear Power Plant.

\section{Surface WATER Temperature MeAsurements}

The Turkey Point Nuclear Power Plant utilizes an extensive canal system (shown on the cover and in Figures 2 and 3) to cool heated discharge water. Plant personnel operate three sites for permanent water temperature measurements: "Intake" (Figure 4), "Discharge" (Figure 5), and "Hotel 1" (Figure 6). These sites utilize platinum resistance probes housed in polyvinyl chloride (PVC) tubes for protection. SRTC set-up three additional sites to augment the plant water temperature measurements: "A", "B", and "C" shown in Figure (7). Figures 8 and 9 show typical installations at the "A", "B", and "C" sites. 
Final MTI Data Report: Turkey Point Nuclear Power Plant (U)

Savannah River Technology Center

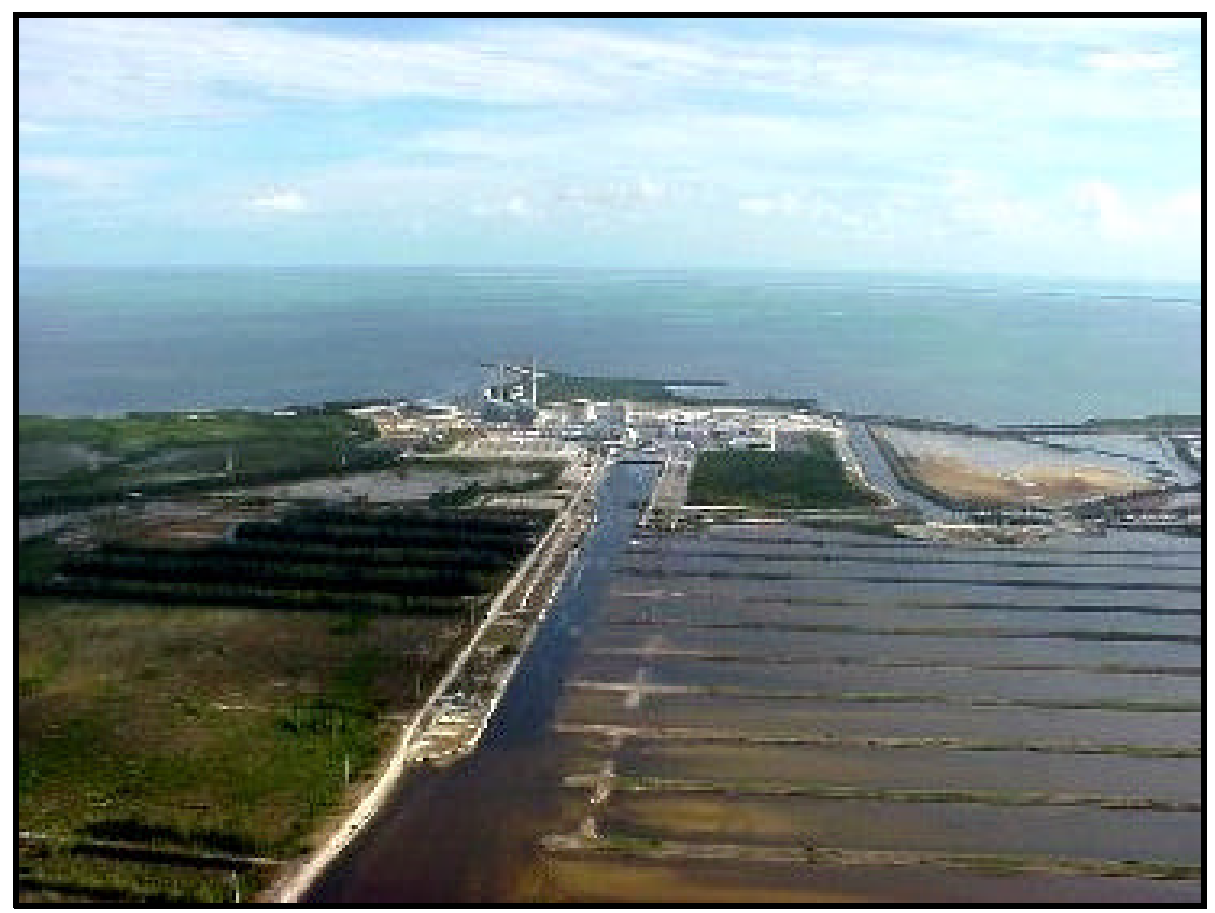

Figure 2. Looking east over cooling canals toward the plant site with Biscayne Bay in the distance.

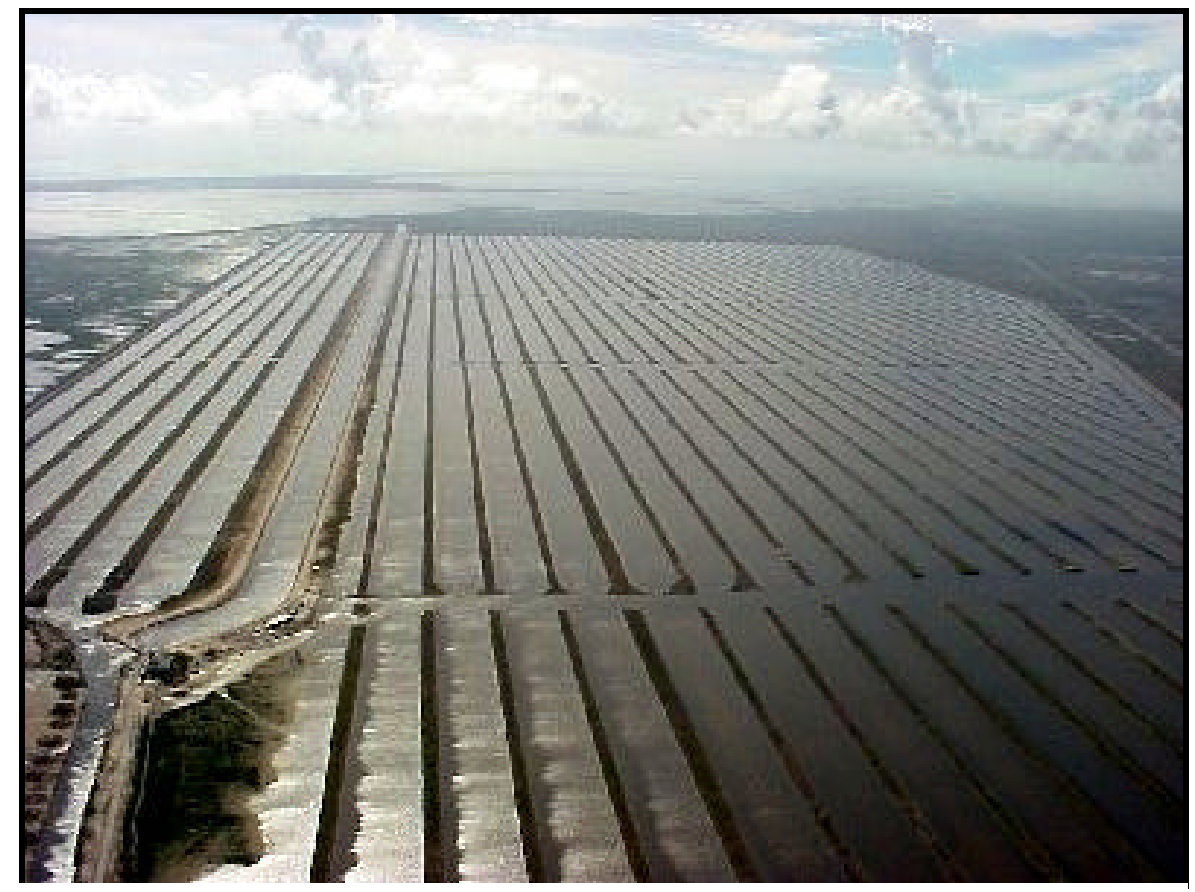

Figure 3. Looking south along the extensive network of cooling canals.

October 2002 


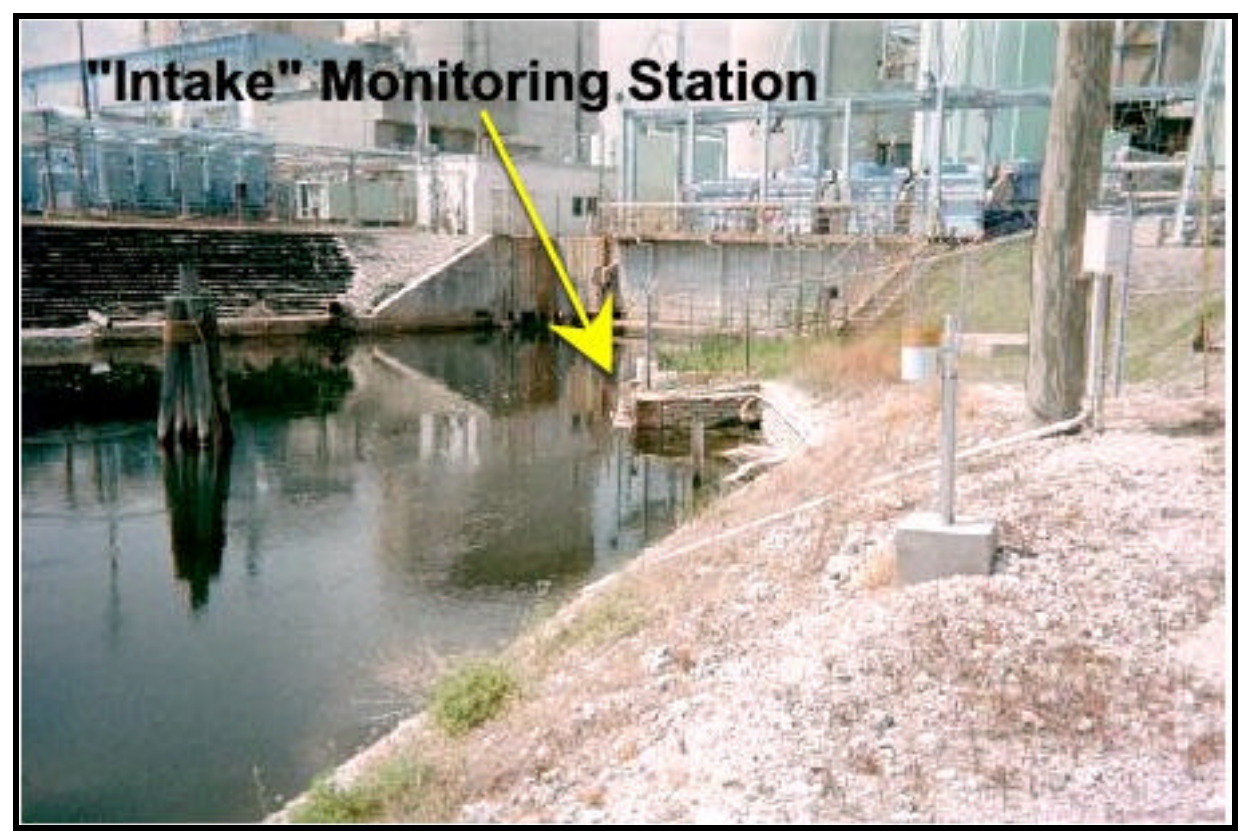

Figure 4. "Intake Site", The water temperature is located within the PVC pipe that extends into the water.

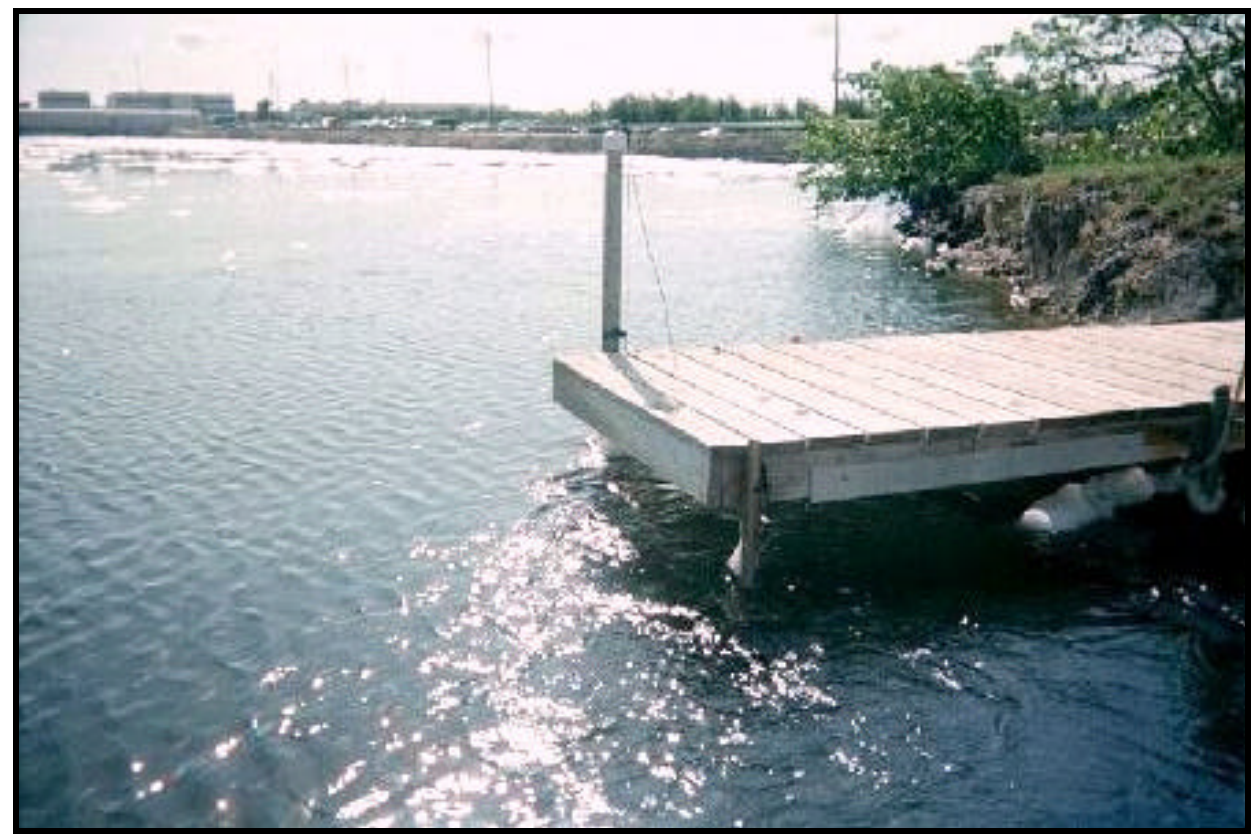

Figure 5. "Outfall" Site, looking south along the extensive network of The water temperature sensor is located within the PVC pipe that extends into the water. 
Final MTI Data Report: Turkey Point Nuclear Power Plant (U)

Savannah River Technology Center

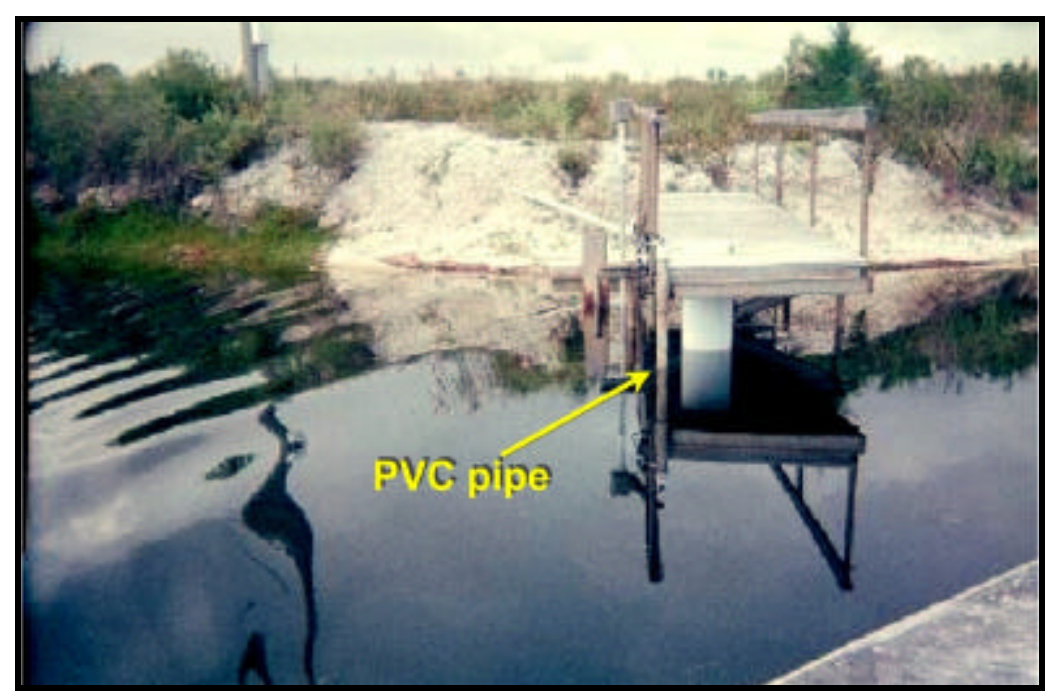

Figure 6. The "Hotel 1" site. The water temperature sensor is located within the PVC pipe that extends into the water.

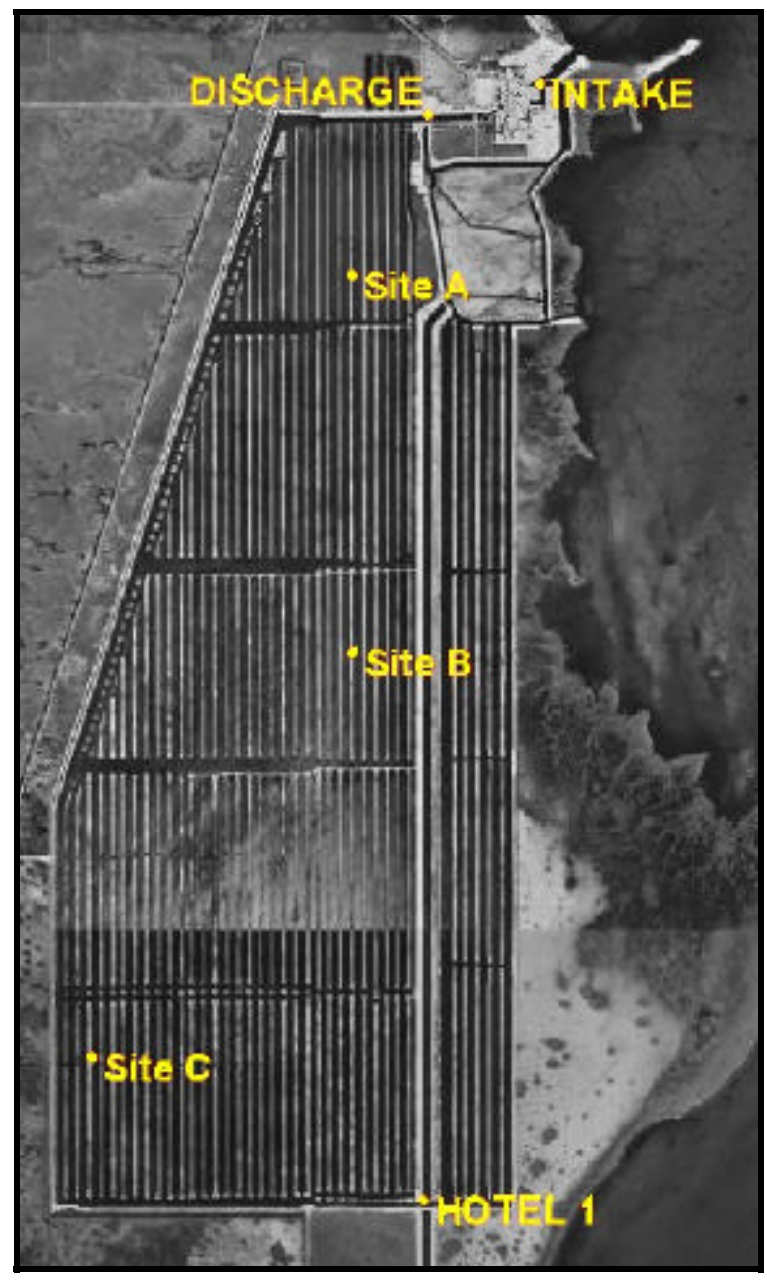

Figure 7. Location of water temperature monitoring sites.

October 2002 


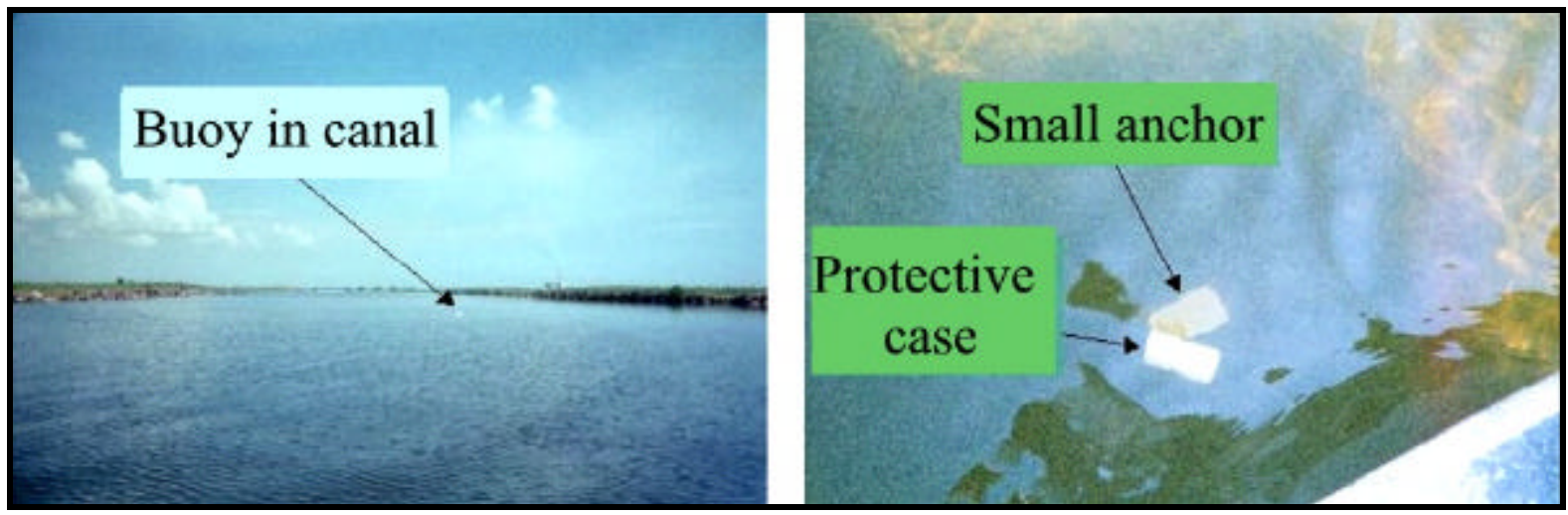

Figures 8 and 9. Typical installations for sites “ $A$ ”, “ $B$ ” and " $C$ ” are shown. The image on the right is a downward looking view of the protective case, which houses the sensor, suspended over a small anchor.

Surface water temperature measurements were made with the StowAway ${ }^{\circledR}$ TidbiT® (Figure 10) manufactured by Onset Computer (www.onsetcomputer.com). Sensors were suspended within a protective case approximately in the middle of the $1 \mathrm{~m}$ (approximate average depth) water column. Data collection was fairly good except for periods where sensors were damaged by resident wildlife, i. e. American Crocodiles (Figure 11).

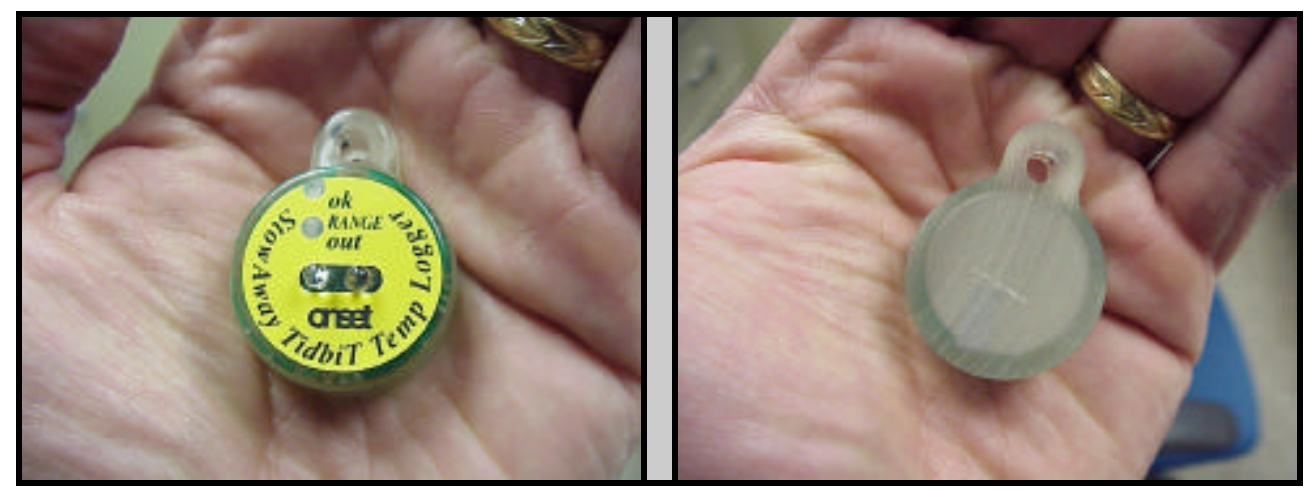

Figure 10. The StowAway ${ }^{\circledR}$ TidbiT ${ }^{\circledR}$ (front view, left, and rear view, right).

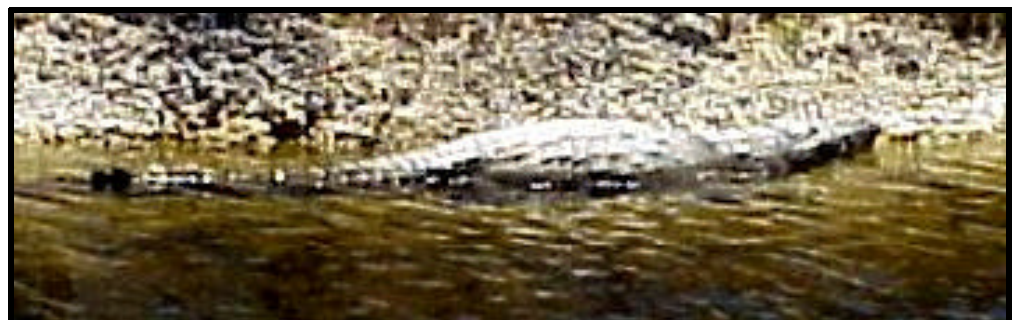

Figure 11. Photograph of an American Crocodile in a cooling canal. 
Hand-held GPS coordinates for each site are as follows:

\begin{tabular}{|lc|}
\hline \multicolumn{1}{|c|}{ Site } & WGS 84 \\
Intake & N $25^{\circ} 25.347^{\prime}$ \\
& W $80^{\circ} 20.624$ \\
Outfall & N $25^{\circ} 25.991^{\prime}$ \\
& W $80^{\circ} 20.275^{\prime}$ \\
Hotel 1 & N $25^{\circ} 21.429^{\prime}$ \\
& W $80^{\circ} 20.338^{\prime}$ \\
A & N $25^{\circ} 25.348$ \\
& W $80^{\circ} 20.624$ \\
B & N $25^{\circ} 23.758^{\prime}$ \\
& W $80^{\circ} 20.630^{\prime}$ \\
C & N $25^{\circ} 22.053$ \\
\hline
\end{tabular}

\section{DATA DESCRIPTION}

The following information in Table I describes surface water temperature data within the file ABCall.xls. All times are local Eastern Time (Standard or Daylight). Turkey Point plant personnel have compiled daily plant operating and meteorological data summaries corresponding to each month of the collection campaign.

Table I. Description of Data Nomenclature

\begin{tabular}{|c|c|}
\hline \multicolumn{2}{|c|}{ SURFACE WATER TEMPERATURES } \\
\hline Name & Description (All temperatures ${ }^{\circ} \mathrm{C}$ ) \\
\hline "A" & Water temperature in the upper canal system \\
\hline "B" & Water temperature in the middle canal system \\
\hline
\end{tabular}




\section{PLANT OPERATING DATA}

Name

\section{Description}

"JULIAN" Julian date

"UNIT 1 MW" $\quad$ Power level of Unit 1 in megawatts

"MAX OUTLET T" $\left(3^{\text {rd }}\right.$ Column $)$ Unit 1 maximum outlet water temperature during the day of record

"UNIT 2 MW" $\quad$ Power level of Unit 2 in megawatts

"MAX OUTLET T" $\left(5^{\text {th }}\right.$ Column $)$ Unit 2 maximum outlet water temperature during day of record

"UNIT $3 \mathrm{MW} \quad$ Power level of Unit 3 in megawatts

"MAX OUTLET T" $\quad\left(7^{\text {th }}\right.$ Column $)$ Unit 3 maximum outlet water temperature during day of record

"UNIT 4 MW" $\quad$ Power lever of Unit 4 in megawatts

"MAX OUTLET T" $\left(9^{\text {th }}\right.$ Column $)$ Unit 4 maximum outlet water temperature during day of record

"PTF CWP OUT" Number of cooling water pumps (fossil) not operating

"PTN CWP OUT" Number of cooling water pumps (nuclear) not operating

"FLOW" Cooling water flow rate/gpm

\section{METEOROLOGICAL DATA}

"JULIAN" Julian data

"HOUR" Time in Easter Standard Time

"DISCHARGE" $\quad$ Plant discharge water temperature in ${ }^{\circ} \mathrm{F}$

"INTAKE" $\quad$ Plant intake water temperature in ${ }^{\circ} \mathrm{F}$ 


$\begin{array}{ll}\text { "HOTEL 1" } & \begin{array}{l}\text { Water temperature }\left({ }^{\circ} \mathrm{F}\right) \text { at the end point in the canal system before } \\ \text { water is transported back to the plant }\end{array} \\ \text { "WIND SPD" } & \text { Wind speed in MPH } \\ \text { "WIND DIR" } & \text { Wind direction in degrees } \\ \text { "AIR TEMP" } & \text { Air temperature in }{ }^{\circ} \mathrm{F} \\ \text { "RH" } & \text { Relative humidity in \% } \\ \text { "PRESSURE" } & \text { Barometric pressure (Note: This data is rarely available) } \\ \text { "COVER" } & \text { Solar radiation in langleys per hour }\end{array}$

Note: "NR" means "NOT REPORTED" in the data files

\section{Data Quality Assurance}

All surface water temperature collected by SRTC data were reviewed for accuracy. Erroneous data were deleted and left as "blanks" in the data files.

\section{EXAMPLE DATA}

An example surface-water temperature plot of quality assured data is shown in Figure 12. An example of plant data is shown in Figure 13.

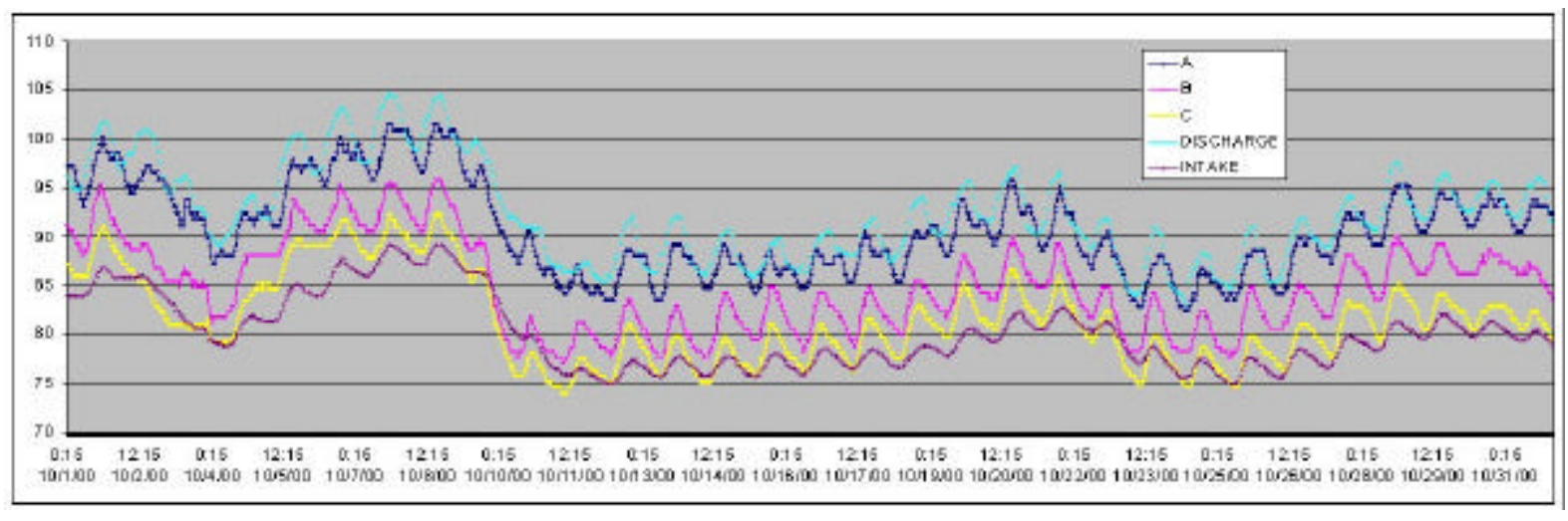

Figure 12. Time series plot of water temperature $\left({ }^{\circ} \mathrm{F}\right)$ data collected at sites " $A$ ", " $B$ ", " $C$ ", "Discharge" and "Intake" ("Hotel 1" data not available) in October 2000. 


\begin{tabular}{|c|c|c|c|c|c|c|c|c|c|c|c|}
\hline JULIAN & UMIT $1 \mathrm{LWN}$ & WAXX OUTLETT T & UNIT 2 BSU & MAXX OUTLET T & UWIT 3 atW & LAX OUTLET T & URT \& BNV & MAX OUTLET T & PTF CWP OUT & PTN CWP OUT & FLOW \\
\hline 275 & 6,077 & 500 & 6.227 & 160 & 17.820 & NR & a & NR & 0 & 4 & 759,373 \\
\hline 276 & 7,415 & 99 & 6.173 & 99 & 17.732 & MR & a & UR & 0 & 4 & 759,373 \\
\hline 277 & 3,708 & 94 & 6.444 & 94 & 17949 & MR & 0 & MR & 0 & 4 & 759,333 \\
\hline 278 & 0 & 82 & 6.900 & 95 & 18.023 & AR & 0 & UR & 0 & 4 & 700,333 \\
\hline 279 & 5,923 & 98 & 7359 & 58 & 17874 & MR & a & MR & 0 & 4 & 798,333 \\
\hline 280 & 8,045 & 100 & 3,109 & $1 \mathrm{E1}$ & 17741 & MR & 0 & MR & 0 & 4 & 759,333 \\
\hline 281 & 6,845 & 102 & 6,125 & 161 & 176553 & AA & 0 & AR & 0 & 4 & 794,333 \\
\hline 282 & 6,437 & 902 & 5,611 & 161 & 17,679 & MR & a & HR & (0 & 4 & 759,333 \\
\hline 283 & 3,912 & 96 & 4,736 & 95 & 17,772 & AR & a & AR & a & 4 & 759,339 \\
\hline 284 & 0 & 04 & 5,103 & 90 & 10.056 & AR & a & MR & 0 & 4 & 759,373 \\
\hline 285 & 0 & 79 & 3.741 & 84 & 18205 & NR & 0 & MR & 0 & 4 & 759,393 \\
\hline 286 & 4,080 & 09 & 5.734 & 88 & 18.132 & MR & 0 & HR & 0 & 4 & 759,333 \\
\hline 287 & 3,908 & 90 & 6.244 & 88 & 18.185 & AR & 0 & AR & 0 & 4. & 700,333 \\
\hline 288 & 1,550 & 84 & 5.492 & 88 & 18,198 & UR & a & UR & 0 & 4 & 790,333 \\
\hline 289 & 0 & 79 & 1939 & BS & 18.185 & MR & 0 & UR & 0 & 4 & 759,333 \\
\hline 290 & 4,953 & 90 & 1.135 & $B 2$ & 18.171 & AA & 0 & NR & 0 & 4 & 799,333 \\
\hline 291 & 5,007 & 91 & 0 & 78 & 18,151 & AR & 0 & AR & 9 & 4 & 690,583 \\
\hline 292 & $5,40 ?$ & 91 & 0 & 80 & 18,154 & MR & a & MR & 1 & 4 & $690,56.3$ \\
\hline 293 & 5,029 & 93 & 0 & 81 & 10.058 & AR & a & AR & 1 & 1 & 690,563 \\
\hline 294 & 4,953 & 94 & 0 & 82 & 19.010 & HR & a & MR & 1 & 4 & 690,503 \\
\hline 295 & 4,290 & 95 & 2719 & 91 & 17,956 & AR & 0 & AR & 0 & 4 & 750,333 \\
\hline 296 & 3,242 & 93 & 0 & 82 & 17.948 & UR & 0 & AR & 0 & 4 & 700,333 \\
\hline 297 & 4,215 & 91 & 2776 & 91 & 18.975 & UR & 2,014 & AR & 0 & 0 & $1,728,000$ \\
\hline 298 & 5.093 & 90 & 0 & 78 & 18.137 & AR & 3,903 & NR & 0 & 0 & 1728,000 \\
\hline 299 & 4,518 & 91 & 3,742 & 91 & 18.219 & HA & 7,6886 & AR & 0 & 0 & $1,728,000$ \\
\hline 300 & 7,829 & 91 & 14 & 79 & 18.176 & A月 & 12,560 & AR & 0 & 0 & $1,728,000$ \\
\hline 301 & 4,573 & 92 & 0 & 81 & 18,099 & MR & 17.625 & NR & 0 & a & $1,728,000$ \\
\hline 302 & 1,550 & 95 & 3,155 & 94 & 18.056 & HR & 17.633 & AR & 0 & a & $1,728,000$ \\
\hline 303 & 4,426 & 95 & 0 & 83 & 10.742 & MR & 18,178 & NR & 0 & 0 & $1,728,000$ \\
\hline 304 & 5,658 & 95 & 0 & 82 & 18.012 & MR & 17.500 & MR & 0 & a & $1,728,000$ \\
\hline 305 & 4,846 & 93 & 3.050 & 90 & 18.036 & UR & 17,630 & UR & 0 & 0 & $1,728,000$ \\
\hline & \multicolumn{2}{|c|}{ PIR NOT PFPORTED } & & & & & & & E & & \\
\hline
\end{tabular}

Figure 13. An example of the plant data for October 2000. See Table I "Plant Operating Data" for a description.

\section{ACKNOWLEDGEMENTS}

Special thanks to Ralph Heistand and Kirk Dudley of Florida Power \& Light for assisting with sensor deployment and recovery. Eliel Villa-Aleman of WSRC provided aerial imagery of the cooing canal system.

\section{REFERENCES}

Garrett, A. J., R. J. Kurzeja, B. L. O’Steen, M. J. Parker, M. M. Pendergast, and E. VillaAleman, 1999: Ground-Truth Measurements Plan for the Multispectal Thermal Imager (MTI) Satellite. WSRC-TR-99-00455. Westingho use Savannah River Company, Aiken, SC. 